\title{
The Female Resisters Under the Patriarchy in Song of Solomon
}

\author{
JING Jing \\ Changchun University, Changchun, China
}

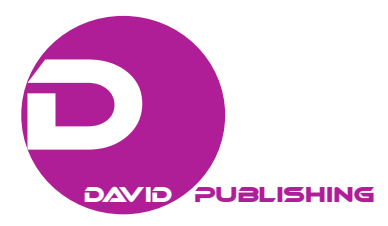

\author{
JING Xia \\ No. 20 Junior Middle School of Siping, Siping, China
}

\begin{abstract}
The present paper is an analysis of the female resisters under the patriarchy in the African-American female writer, Toni Morrison's Song of Solomon, which was published in 1977 and won the National Book Critics Circle Award and American Academy and Institute of Arts and Letters Award. The paper focuses on how the females in Song of Solomon—Ruth and her Daughters—resist the patriarchy.

Keywords: feminism, female resisters, resist the patriarchy
\end{abstract}

\section{Introduction}

Toni Morrison, the only black woman who wins the Noble Prize for Literature, is considered to be one of the greatest contemporary novelists. She has written eight novels, all of which are well-received by the public. She finished her third novel Song of Solomon which was published in 1977 and won the National Book Critics Circle Award and American Academy and Institute of Arts and Letters Award. Song of Solomon is rich in content and profound in thought. Since its publication, it has attracted numerous studies from different perspectives and plays an important role in American literature.

Morrison does smartly well in projecting black women's angst under the double oppression of both black men and white ones. DONG then made a conclusion that "one has to consider not only a black woman's life experience and living environment but also her gender and sex in order to understand Morrison's fiction well” (1986, p. 143).

Song of Solomon is different from Morrison's other works. It is the only one that she chooses a man as the protagonist. The protagonist is Macon Dead III whose nickname is Milkman. He gets the name because he is still breastfed by his mother during his childhood. This novel depicts Milkman's search for his self-identity, family history, and cultural returning. Although the protagonist is a man, we can still find vivid female characteristics through him. This paper will choose three females: Milkman's mother—Ruth, and his two sisters—Corinthians and Lena, as to analyze their potential resistance when they face both racist oppression and patriarchy.

\section{The Situation of Black Women}

Black women have been suffering the inhumane treatment for a long time.

Any body white could take the black whole self for anything coming into white's mind. Not just work, kill, or maim the black, but dirty the black. Dirty them so bad them couldn't like themselves anymore. Dirty them so bad them forgot who they were and couldn't think it up. (Morrison, 2004, p. 251) 
From this example we could see the black women are in the lowest position in American. They do not have freedom and they just do anything that Whites demand.

"History had estimated a fact that only depending on the strength of the black themselves, the condition of them could never be changed" (Taylor, 1994, p. 256). At first, the image of black women is obedient and docile, they do not dare to rebel against slavery, they do not dare to change their living conditions. But it is not absolute about this view. They have begun to fight, but the enemy is the whole America, and at the same time, they are lack of skills and strategies in the battle. So they dare to rebel, but they are not strong enough. Because of the evil condition, they just could change their situation slowly. From these, we could see the progress of black women. They are not obedient, menial, and low-down any more. They begin to rebel.

\section{Ruth and Her Daughters—-Resisters Under the Patriarchy}

Black women have been suffered sexist and racist oppression under Slavery System for a long time. Even after the Slavery is abolished, the situation of black women does not change too much. Now the black women begin to rebel against slavery to pursue their own freedom, their rights, and their identities.

The tragedy of Southern women lies in that the society was dominated by men. Women are living in a man-centered society that only with narrow space of life and this kind of life makes women almost smother. In the Southern society, on one hand, men are polite to women and always play protectors for women on the surface, but actually women are not respected by the men and they have no identity and right; and on the other hand, women are recognized as the source of all evils and troubles by men. In real life in the South, men deny women's identity and women are allowed to have themselves emotions but not have the autonomy. Women must obey men completely and become their servants, sisters, friends, wives and lovers. At that time, women belong to men but men do not belong to women. The women's low status indicates that women are not treated normally but only is a tool of giving birth to a baby and help the men achieve men's grand blueprints. The women chastity is viewed holy and sacred although women are as tools of delivering and as appendixes of men. Southern ladies' love are pure, the basic requirement for a pure Southern lady should have no desire and no passion for life and should not have feeling as cold as ice. This kind of women opinion is not aiming at protecting women's life and not women's basic human rights but only is their chastity. This kind of women view and life in men's supremacy, the situation of women is a tragedy, women only can keep their chastity, and they have nothing if they lose their chastity.

In Song of Solomon, apart from the racism of white people, black females were also suppressed by patriarchy. They attached to male-dominated society. In the novel, different images of females are described. No matter in their families or in the society, they were placed in passive positions. Worst of all, they suffered long-term patriarchal repression. Fortunately, readers can find out different methods of protest from them. Ruth and Milkman's sisters were both the victims of the patriarchal society.

Ruth is Milkman's mother. Her full name is Ruth Dead which demonstrates her terrible life. She depends on her husband and wealth to live during her whole life. She has not personal identity and always leeches on to the male-dominated society. But such a woman once disobeyed her husband's will. Ruth was spoiled by her father, the first and only doctor in that town. From Macon, we knew that after Ruth's father died, she lay beside her father and kissed his fingers in her mouth. Seeing that, Macon showed contempt for her and no longer had sex life with her. At that time, she was only 20 years old. Ruth became a stupid and awkward servant in Macon's eyes. 
She had to face her husband's indifference at any time. Nevertheless, Ruth had strong wills sometimes. She wanted to have a child with Macon and hoped that the pregnancy could improve the conjugal relation between Macon Dead and her. She fed Macon a kind of aphrodisiac made by Pilate. Fortunately, she was successful but when Macon was awake from erotic passion, he tried to adopt brutal ways to kill the child. Unlike Pilate, Ruth was not independent or brave; she could not fight against Macon publicly. However, she adopted all kinds of methods to protect the child. She united with Pilate. Pilate brought a voodoo doll inserted by a silver needle to threaten Macon. When Macon forced Ruth to stab the needle into her uterus, she only inserted part of the needle to keep the child.

Ruth is a weak and timid woman but she would do anything for her son even sacrificing for him. When she learnt that Hagar wanted to kill Milkman, she went to Pilate's home and warned Hagar that nobody can hurt her son. However, she was not looked upon as a respected mother. In Milkman's eyes, his mother was a feeble-minded woman. Because Milkman was influenced by what he constantly sees and hears from his father. He was subjective, indifferent, and mean like his father.

There is no doubt that life is a tragedy for Ruth. As her name suggests, she is living in a dead life. From the novel, we can see one Ruth, but there are thousands of "Ruth" in our mind. Like the Ruth in the novel, they are victims of patriarchal society. In such a society, they have no rights to speak and they cannot express their own thoughts and opinions. But sometimes, they made subtle ways to defuse dilemma in life. In other words, it is a kind of wordless struggle.

Same as Ruth, her two daughters, Corinthians and Lena were also victims of patriarchy. Morrison not only reveals their oppressive life but also their struggle for freedom. Readers can see their inward courage from their dialogues and behaviors. Actually, all of them possess rebellious consciousness.

Macon's eldest daughter lived a kind of reclusive life. Afraid of her mother being bullied in home, Lena abandoned the opportunity to go to college. Her freedom was restricted by Macon so what she could do was to make artificial rose petals in the patriarchal house. Actually, Lena was a black girl with extraordinary personality, but she suppressed her heart all the time. When the emotion burst out, she was destined to be valorous. When her sister, Corinthians fell in love with one of her father's tenant, Milkman reported it to Macon. He explained that he was responsible for his sister's sake. Actually, he believed that it was wrong for his sister to marry a poor man. In order to help her sister to pursue happiness, Lena told Milkman the thoughts that depressed her many years,

What do you know about somebody not being good enough for somebody else? And since when did you care Corinthians stood up or fell down? You have been laughing at us all your life. Corinthians, Mama. Me. Using us, and judging us...But now, all of a sudden, you have Corinthian's welfare at heart and break her up from a man you don't approve of. Who are you to approve or disapprove anybody or anything? (Morrison, 2004, p. 215)

At the meantime, she declared that she no longer made artificial roses. Actually, her behavior was a kind of challenge to patriarchy.

Corinthians accepted college education in France but stayed at home making artificial roses with her mother and sister. When she was 42, she felt bored and determined to get a job. Actually, she just wanted to escape the patriarchy home and get the feeling of independence. It was her first step to break traditional manacles. Macon Dead took control of home finances and determined his children's education and marriage. He sent his daughter to college not for getting better education but letting her marry into a middle-class family. However, the thing got 
the opposite of what he wanted. Corinthians fell in love with a common laborer. After encountering her father and brother's prevention, she got into trouble. As Corinthians's lover Henry Porter pointed out, Corinthians was just a doll. She obeyed family's manipulation and had not her own thoughts. And he declared that he needed a mature woman as a wife. In other words, the women like Corinthians were male's decoration. She experienced internal struggle over and over again and finally set foot out of the patriarchy house, living in a workers gathered building. She pursued her new life bravely.

As a matter of fact, Corinthians and Lena's extraordinary behaviors had some positive effects on the disintegration of Milkman's patriarchal consciousness. They kept silence many years and eventually set off the step to pursue their own life. They found a road to get liberation and freedom.

It is not difficult to see that Milkman and his father never respected women. They considered women as dolls so they could manipulate them at their pleasure. Ruth, Corinthians, and Lena lived in the patriarchal-dominated family. They had no freedom to love and they were deprived the right to be loved. However, they used their own ways to challenge the patriarchal-dominated society and chose life according to their own wills. There is no doubt that all of them were victims of the society. Through the three women, Morrison expresses her yell about female's oppression under patriarchy and the patriarchal society. What is more, Morrison intends to tell us how to win self-liberation if black women want to walk out the terrible dilemma. On the one hand, black women should be self-reliant and they must get rid of the traditional view's constraint that focuses on male in love and family life. What is more, they should become independent individuals both materially and mentally. On the other hand, black women should bear self-identity in mind and carry forward the national spirit. The last but not least, black women must learn how to love and be loved and then establish a beautiful world without oppression or discrimination.

\section{Conclusion}

Song of Solomon is different from Morrison's other works. It is considered to be the most optimistic and hopeful novel. Unlike her former works, Song of Solomon is the only novel that she chooses a man as the protagonist. Although the protagonist is a man, we can acknowledge vivid female characteristics through him. Milkman's mother and his two sisters possess tragic life. Because of long-time patriarchal oppression, they are deprived of rights to love and be loved. Because of racism and white-dominated culture, they lose their identities and self-independence. But we can see their inward courage from their dialogues and behaviors. Actually, all of them possess rebellious consciousness. Milkman's mother-Ruth tried her best to make subtle ways to defuse dilemma in life. In other words, it is a kind of wordless struggle. And Milkman's two sisters-Corinthians and Lena's extraordinary behaviors had some positive effects on the disintegration of Milkman's patriarchal consciousness. They kept silence many years and eventually set off the step to pursue their own life. They found a road to get liberation and freedom. They are potential resisters under the patriarchy in Song of Solomon.

To solve the racial discrimination and sex oppression, not only the black women themselves try their best, but also the government and the whole nation should make some efforts. After oppressed by racial discrimination and sex discrimination for several centuries, nowadays, the black women have equal rights in many aspects. In their daily life, they are accepted by society and they can have their own jobs. Their social position also is raised, they can become leaders of companies or stars in media, and some of them even in the army or the government. In 
political aspect, they have equal rights as Whites and they can vote and be voted.

\section{References}

Dong, D. S. (1986). Double shackles on Afro-American women writers. Reading, 4, 136-143.

Fanon, F. (1976). Black skin, white mask. New York: Grove Press.

Geertz, C. (1973). The interpretation of cultures. New York: Basic Books.

Segy, L. (1976). Masks of black Africa. New York: Dover Publications.

Taylor, G. (1994). Conversations with Toni Morrison. Jackson: University Press of Mississippi.

Morrison, T. (1994). Song of Solomon. New York: Alfred A. Knoof.

Morrison, T. (2004). Song of Solomon. New York: Random House. 